\title{
COVID-19 Mutual Disabilities in Edo State Gubernatorial Electoral Process
}

\author{
O. Adisa ${ }^{1, *}$ and R. Asuelime ${ }^{2}$ \\ ${ }^{1}$ School of Social Sciences, College of Humanities, University of KwaZulu-Natal, South Africa \\ ${ }^{2}$ School of Arts, College of Humanities, University of KwaZulu-Natal, South Africa
}

\begin{abstract}
The conduct of elections in Nigeria is generally associated with manipulation, which has often undermined the credibility and fairness of the process since the country gained its independence. COVID-19 poses a very serious challenge to the electoral process, considering the nature of the disease, which has led to the promotion of limited physical interaction as an approach to mitigate its transmission and safeguard the health of the people while at the same time impacting negatively on state's electoral justice. While elections remain a key factor to the attainment of political positions in a democratic setting globally, several scholars and media reports have made attempts to assess the political intrigues in the state of Edo as a result of the tense atmosphere created by political gladiators. The use of the pandemic and various forms of propaganda to destabilise the camp of perceived opponents with the aim of winning public support are notable strategies employed by the main contending political parties and their candidates as the election approaches. Therefore, this article evaluates the impediments and political manoeuvrings in the electoral process in the state of Edo, considering the increasing number of corona-virus infections, the country's frail electoral system, and the desire to maintain credible democratic consolidation in the country.
\end{abstract}

Keywords: COVID-19, democracy, Edo, election, electoral justice, Nigeria, pandemic.

\section{INTRODUCTION}

The electoral process faces very serious impediments, which are not limited to a particular locality or region due to the global pandemic but constitute a very serious threat to peaceful elections everywhere in the world, from pre- to post-election eras. Considering the various issues associated with the conduct of elections in various countries, this unexpected and unplanned scenario constitutes a test of integrity for the process and the procedures in all democratic societies. It is no longer news that even developed democracies have had challenges occasioned by the perceived manipulation of the electoral process. While such instances have undermined the credibility of elections in advanced democracies, the case of the developing nations has been even more critical [1]. The level of electoral fraud and its aftermath has been a major impediment to peace and development in many third world countries. Therefore, this development leads people to the challenge of conducting free, fair, and credible elections in an atmosphere where social distancing and other health-related procedures are preached. In a few countries where elections have been allowed to be conducted during this pandemic, cases of low turnout as a result of fear by voters and poll workers have been reported [2]. While the health of the actors and

*Address correspondence to this author at the School of Social Sciences, College of Humanities, University of KwaZulu-Natal, South Africa;

Tel: +27 625472526; E-mail: lekanadisa@yahoo.com electorates should not be jeopardised, the possibility of adhering strictly to democratic principles while ensuring compliance with regulations as it relates to COVID-19 has also become a major issue of debate [3].

While there are fears over the possibility of conducting peaceful and credible elections in the present circumstances, the likelihood of using the pandemic to prolong stays in power and to shift election dates in developing democracies has also been a challenge [4]. This can easily be associated with the effect of the various measures adopted to minimise the spread of the virus, which could impact the electoral circle as a result of personal interests.

Therefore, the present health concern in society presents a scenario whereby weak and developing democracies face a very critical level of manipulation by political elites who could influence the system due to unforeseen circumstances. The various institutions, therefore, face a germane responsibility of ensuring the rules and procedures are not compromised so as to ensure the fairness of the electoral process with the aim of guaranteeing the motives of democratic governance.

\section{CONCEPTUAL CLARIFICATIONS}

\section{Mutual Disability}

Oxford English dictionary [5] describes mutual as common, shared experiences as a result of interpersonal relationships. This can be referred to as 
an activity or event which binds two or more people together. It further defines disability as the inability to express required physical or mental abilities to their full potential, which leads to a disadvantage [6]. While disability often relates to human incapacity, the term could also qualify any limitation of human desires and actions. Therefore, mutual disability, as a concept, refers to the identification of a general obstruction to a process that is not limited or specific. Therefore, in the context of elections, it becomes a major setback for all political actors in a bid to participate as required due to unforeseen or uncontrollable factors actively.

\section{Electoral Process}

The electoral process can be described as the total activities which drive the organisation and selection procedures in a political system. It is expected to be guided by democratic principles as a condition to sustain and maintain fairness for all parties and individual actors [7]. The process extends from political parties to voters and the declaration of results, which also gives an avenue to seek redress from the courts [8]. UNDP [9] in 2009 identifies the electoral process as an ingredient that can help maintain peaceful coexistence when properly managed and become a catalyst for conflicts when it is not properly managed.

\section{COVID-19 Pandemic}

The emergence of the COVID-19 virus in China unexpectedly led to a global challenge to world economies, living conditions, and social interactions. Even though there were initial denials of the existence of coronavirus and the extent to which it may impact the world economy and people's lives. However, the sharp fall in the stock price and economy globally around late February 2020 as a result of fears and the impact of the pandemic has presented a major challenge to the world and how we deal with our daily life [10]. The impact of the virus led to a great number of deaths and lockdowns in several countries, which has further led to uncertainty and a clamour for health protocols in recent times. The use of face masks, temperature testing, and social distancing are common lexicon in people's daily interaction, globally, as a result of the present health crisis. This, therefore, poses an impediment to social interactions, movement, and general activities, globally.

Electoral Justice refers to "the means and mechanisms: for ensuring that each action, procedure, and decision-related to the electoral process is in line with the law...and for protecting or restoring the enjoyment of electoral rights, giving people who believe their electoral rights have been violated the ability to make a complaint, get a hearing and receive an adjudication" [2]. The concept, thus, speaks to the creation of an enabling environment for an election to be considered free and fair, otherwise considered as questionable and illegitimate. Electoral justice moves beyond the general legalities in the country concerned and gives the people an open environment in which they are not only able to exercise their electoral rights but believe and feel that they are enabled to do so and satisfied with the system [11]. Electoral Integrity Group [12], for instance, argues that;

"Realisation of Electoral Justice requires a set of institutions, practices, norms, mechanisms, practices, and procedures that culminate in fair and open processes by which citizens choose those who are to govern them and to hold them to account - and this not simply on polling days but on a day-to-day basis. Electoral Justice gives people who believe their electoral rights to have been violated the ability to make a complaint, get a hearing, and receive an adjudication within a reasonable time."

\section{ELECTIONS IN A DEMOCRATIC SOCIETY}

As a process, elections stimulate a democratic system and act as a catalyst for managing political actors in an orderly manner for ease of succession. While elections serve as a medium for transition, they do not guarantee sustainable democratic transitions. Schedler [14] identifies the possibility of the emergence of an authoritarian government, which can also be used to perpetuate a government in power. In the opinion of Adejumobi [15], elections can lead to a disguised democratic rule, which ultimately limits the options available to the electorates or undermines their ability to make independent decisions.

Therefore, it would be reasonable to conclude that elections may not actually lead to a consolidated democracy. However, it is important to highlight that regular and periodic elections are a basic tenet of democratic governance [7]. It has also been proven that the plausibility of elections yielding a successful transfer of power depends on the impartial administration of elections [16]. This highlights the importance of people's preferences in choosing their leaders as a necessity towards sustaining democracy. 
It is also argued that electoral systems are often regarded as the foundations of any nation's national politics and play a vital role in the peaceful coexistence and general development of society.

\section{CHALlENGES TO ELECTORAL PROCESSES FROM A GLOBAL PERSPECTIVE}

Electoral conduct could face challenges, especially when the conduct does not present a fair process for all parties. A legitimacy crisis often arises as a product of electoral manipulation, which often hinders the credibility and acceptability of the exercise [7]. The quality of elections plays a major role in its categorisation as legitimate or flawed [12]. Ebirim [17] describes electoral malpractice as a process by which the rules and regulations that govern the conduct of elections are manipulated to favour specific interests. In a similar vein, Bamisaye and Awofeso [18] categorises electoral malpractice as a reflection of the determination of politicians, political actors, and political parties to capture power without the recourse of procedures and regulations. According to Norris et al. [19], election rigging alludes to electoral influences, which are obvious illegalities perpetrated through a corrupt, deceitful, or sinister intention to impact a political decision in favour of a particular competitor.

A particularly important concept, critical to any discussion of election, is democracy. Schumpeter [20] describes democracy as the act of filling governmental offices through elections. It is believed that democracy is a regime in which leaders are selected through free and contested elections. Therefore, from the previous, it has become impossible to imagine democracy without elections [21].

Therefore, the submissions above lay credence to the role of elections in a democracy and transitions of power. Przeworski and Limongi [22] submits that a successful transition depends on the desire of society to evolve into a pragmatic and holistic community. Huntington [23] buttresses this argument by emphasising the importance of values and stability in democratic consolidation. However, while democracy faces different challenges depending on the society concerned, it is obvious that the consolidation of democracy can only be achieved by playing the game according to the rules.

\section{THE ELECTORAL PROCESS AND THE COVID-19 PANDEMIC}

The concept of democracy, which encompasses the electoral process, originates from the term kratia, meaning rule, and demo, meaning by the people [8]. It has been equally summarised that democracy means responsibility as well as rights. Responsibility to respect diversity, to fight inequality, and to show solidarity [24]. Democracy can, therefore, be classified as a socially responsible and self-determinant collective for the good of society. In addition, global analysts have also argued that democracy should have benefits as a direct function of the application of democratic conditions [7].

Hounkpe and Gueye [25] highlight the significance of serving the interests of the people as one of the cardinal principles of representative democracy. This is closely related to the ability to select representatives among contending candidates, which, therefore, gives room for healthy competition [26]. The ability to freely express and avail the electorates offers the opportunity to evaluate candidates and, therefore, becomes an important factor in the electoral process. However, the covid-19 virus has been a major issue that has limited the ability of interaction of people.

The conduct of elections has been generally hampered by COVID-19 in different ways. The process has been postponed in about seventy countries since the virus became a global issue, while voter turnout has been decreased as a result of health concerns [27].

\section{POLITICAL ACTORS AND THE PANDEMIC IN EDO STATE}

The incumbent Governor of Edo State, Godwin Obaseki, was supported by Mr. Aliyu Oshiomhole, who is the predecessor and immediate past National Chairman of the All Progressive Party (APC), as he emerged the leading candidate of the party in 2016 [28]. However, after his emergence as Governor, political differences led to the removal of perceived supporters of Oshiomhole from office, leading to the refusal to inaugurate lawmakers loyal to his political godfather and the eventual suspension of the National Chairman by the local APC executives in his ward [29]. Events leading to the renewal of Obaseki's mandate further polarised the party into two factions, as Pastor Ezeyamu, a notable politician who was the main opponent presented by the opposition party (PDP) in the 2016 governorship election, returned to the APC and was welcomed by Oshiomhole.

The process of selecting the party's flag bearer, therefore, generated a lot of controversies as Pastor Ezeyamu enjoys the support of the Oshiomhole led executives, which is saddled with the administration of 
the party. The first of the controversies was the allegation of inconsistencies in the academic credentials of the incumbent Governor during the screening exercise and his eventual disqualification from the race. Secondly, while the national secretariat of the APC ruled out using the indirect primaries for selecting its candidate, the party accused the Governor of anti-party activities due to the publication of a gazette that banned political gatherings in the state [30]. The Governor had been an advocate of the indirect primaries while the party hierarchy, at its centre, supported the direct primaries in choosing the candidate who would run for the office of Governor in 2020 [31].

Therefore, the emergence of a quarantine regulation entitled, "Infectious Diseases (Emergency Prevention) Regulation 2020", with the aim of addressing the spread of covid-19 in the state, was perceived as a political decision to thwart the efforts of conducting the preferred mode of primaries by the APC. The gazette, among other provisions, stipulates:

"That in respect of political gatherings for the purpose of conducting primaries for any of the parties desiring to field candidates in the forthcoming gubernatorial election, gatherings of more than 20 persons may be allowed, subject to the written approval of the governor, if such gatherings do not exceed 5,000 persons; hold in Benin City and in a single facility with a large seating capacity of not less than 10,000 persons; are provided with adequate health, safety and sanitary facilities and are COVID-19 response compliant with social distancing policy, hand-washing and proper use of face masks fully observed" [31].

The submission of many political analysts to this move by the Governor was indicative of him using his office to create an avenue to prevent the APC from conducting its primaries as desired. While other political parties adopted indirect primaries as a mode of choosing their candidate for the Governorship, only the APC chose the direct method, which ultimately needs party members to assemble in all 192 wards across the eighteen local governments in the state.

Those loyal to the incumbent Governor claimed the decision to invoke the gazette was a necessary precaution to covid-19 and was in compliance with the presidential task force, which had earlier advised states to manage the disease as deemed applicable [30]. However, the APC, at a national level, justified its decision based on the fact that the party does not have an updated register and that it notified the electoral body within a prescribed period of time, as recognised by law. In addition, the party maintained that 21 days' notice, as provided in the electoral Act, allowing for the possibility of changing from their earlier submission to use indirect elections, irreplaceable due to the timeframe [30].

As a result of his disqualification from the contest on the platform of the APC, Obaseki and his deputy defected to the PDP after consulting with the leadership of the opposition and eventually became the candidates for the gubernatorial election. The APC conducted its primaries, and Pastor Ezeyamu emerged as the representative candidate of the party, beating six others who either withdrew or were pushed out of the race [31]. While the battle for the APC ticket, both the incumbent Governor and the candidate of the APC used every avenue to solicit support from notable indigenes of the state, which was evident in the crisis at the palace of the Oba of Benin [32]. Notable individuals and bodies also either pitched their support for the incumbent Governor or Adam Oshiomhole's led camp, which is bent on ensuring Obaseki is replaced [29].

These factors have generated a lot of controversies as Election Day draws nearer and has heightened political tension in the state. The leading political parties (APC and PDP) have both used social media, billboards, disinformation, fake news, and other forms of campaign strategies to undermine the opposition, contrary to the provisions of electoral laws [33]. While this development is unhealthy for the political system, the level of violence arising from these activities also serves as a very unfavourable scenario in a season where health-related protocols and safety precautions are required to conduct elections.

The electoral playing field in Edo has, therefore, created somewhat of a conundrum in the pursuit of electoral justice systems in the state, as the democratic space is festered with allegations of pre-election rigging and more. The electoral political environment, akin to that currently experienced in Edo, usually leads to mass stay-aways by participatory voters as a result of the toxic and heavily polarised process [12]. Among a litany of issues that were raised by the incumbent Governor, Godwin Obaseki, in Edo State since moving to the opposition political party (PDP), was the 
allegation of a possible partisan nature of the security forces in support of the APC and its candidate, Pastor Osagie Ize-lyamu. Since the birth of the APC party at a National level and after winning the national elections in 2015 , the security arms of the state have continued to suggest their neutrality in election-related matters. When the institutions that are sanctioned to protect the people take partisan approaches, the hope of the people in having justice fizzles. In cases of political violence, in which members of the opposition allege victimisation, the aggrieved party could not take their cases to the police as they feared arrest under forged charges or having their cases simply be ignored [34]. However, in the age of COVID-19, social distance regulations, and the Edo State governor's ban on gatherings, the more pressing question is how to understand the role and modus operandi that the security apparatus will be able to play in an environment of a mutually disabled political landscape.

The judiciary, which is also an important pillar of electoral justice, has also received its fair share of criticism as an extension and contributor to confusion as it is used to access COVID-19 related interlocutory injunctions by the Edo state government to impede the electoral activities of the opposition party in the state. This has become problematic to the extent that a number of groups and members of the state are calling for a systematic purging of judges that are seen as easily amenable to the political establishment and have aspirations of becoming the state executive. The role of the judiciary in Nigeria is not expected to be that of interfering with electoral processes, which is a preserve of political parties, except for rare cases of interpreting legal party constitutional documents and letters. Interference amounts to a usurpation of the powers of the parties and their members in electoral matters. The Electoral Act clearly posits that the "authority to govern derives from the will of the people demonstrated through elections that are conducted efficiently, freely, fairly, transparently, and properly on the basis of universal and equal suffrage exercised through a secret ballot" [11]. The judiciary does not only interpret the electoral laws but also stands as the final umpire whose judgment, in cases of electoral disputes, according to the laws and the constitution, is final. However, having an understanding and acting on its powers are two different things. The question, therefore, is how the judiciary has fared in acting up to its mandate as the final umpire in electoral justice systems without compromising the legitimacy of elections in the state of Edo so far. Although, one may argue that the Judiciary does interfere with conferring some sort of legitimacy, as was witnessed in Zimbabwe in 2018. The situation was different there; with the presidency of Emmerson Mnangagwa having risen to power on the back of a quasi-military coup, Mnangagwa needed internal and external legitimacy and, hence, opened room for the courts, specifically the Constitutional Court, to deal with electoral issues so as to appear transparent [35]. It is, nonetheless, alien to the Nigerian constitution.

The debates on the legitimacy of the elections are simply a means through which scholars and commentators judge the arms that are saddled with bringing forth a credible election that the voters accept as impartial. The judiciary takes the position of the final arbiter in all. The judiciary is saddled with the mandate of dealing with all disputes emanating from the manner in which the electoral process unfolds in line with the constitution. It is the last door which any aggrieved parties in the electoral process can knock on with full trust that they will receive a fair judgment. The judiciary, therefore, is the central pillar of the primary electoral justice system, whose strength defines the strength of the national electoral justice system. It is because of this centrality that this paper accords relatively more space for discussing the judiciary and electoral justice in Zimbabwe so as to weigh the strength of the national electoral justice system [11]. For the electoral processes in the state of Edo to find footing in legitimacy, despite COVID-19 exigencies, the Judiciary must ensure that the principles that underpin electoral justices' tenets are not compromised.

Lastly, the role of the media comes in as another primary pillar of the electoral justice system. The media, through its print, audio, and video broadcasts has a dominant reach to most of the citizens. Also, the decisions that are made by the millions of voters are made through the knowledge they have on the participants (political parties and candidates) in the elections. While some of this information may be gathered directly from the political meetings of various candidates, which may be called rallies, the majority of the voters may not be able to attend the rallies [11]. This then poses questions for the political processes in the age of COVID-19 and its many regulations around social distancing, lockdowns, and governmental bans on gatherings. This is more worrisome for remote areas without access to mainstream media. How then do we aggregate the level of electoral justice for these groups with limited access to information and political participation due to COVID-19? 


\section{SUMMARY AND CONCLUSION}

The fact that elections are the bedrock of democratic governance and are clearly an essential characteristic of a consolidated democracy cannot be ignored. However, democracy faces diverse challenges all over the world as the global pandemic creates another dimension to the problems associated with the process. The role of political actors in the election, who may want to exploit the sudden environmental developments to their advantage and outwit political opponent(s), has been a major issue, especially in developing democracies. The state of Edo in Nigeria creates a very intriguing scenario whereby the incumbent Governor, who no longer enjoys the support of his party hierarchy, is accused of using his position to undermine the party's selection process by issuing an executive order which restricts political activities in the state. The Governor's gazette, which became a law forbidding the gathering of more than fifty people in a place, has been linked to a political undertone which was aimed at foiling the use of the party's preferred mode of primary elections for selecting its Governorship candidate. While the APC is entirely responsible for which mode it adopts to choose its candidate, the decision to disqualify the incumbent on the basis of his academic records further raises questions; because he presented the same set of documents when he contested for the candidacy and emerged victorious four years earlier.

Politics in Nigeria are often the survival of the fittest, as most actors often align with parties and each other due to perceived interests or motives rather than ideologies, as the country has experienced with several politicians moving from one party to another. The inability of the incumbent Governor to win the APC ticket due to his disqualification has led to his movement to the PDP as the candidate of the main opposition party. This article clearly exposes the nature and attitude of the Nigerian political elites in their desperate attempt to achieve their desired political aspirations and use whatever means to ensure their victory in the contest. The weak political structures, poverty, and weak institutions, especially the courts, which often provide conflicting rulings, have been fingered as major problems confronting the system. This clearly explains the emergence of individuals as candidates of the two main political parties, even when such persons were not previously in the party and the various court judgments leading to the 2020 Governorship election in the state show clear cases of inconsistencies. The electoral process in Nigeria and most developing democracies no doubt faces very serious tests amidst this Covid-19 pandemic, especially when considering the attitude and disposition of politicians to remain in power by any means.

This paper also interrogated the state of electoral justice in the 2020 Edo State gubernatorial elections. It noted that electoral justice is guaranteed by the availability of important electoral pillars that do not only ensure the legality of the electoral process but its legitimacy as well. To this end, and in the view of the citizens, from whom the mandate and legitimacy to govern is derived from, the Judiciary cannot afford to compromise despite COVID-19 pressures and dynamics.

\section{REFERENCES}

[1] Ajayi K. Election administration in Nigeria and the challenges of the 2007 elections. The Social Sciences 2007; 2(2): 142 151.

[2] Orozco-Henriquez J, Ayoub A, Ellis A. Electoral Justice: The International IDEA Handbook. International Institute for Democracy and Electoral Assistance (IDEA), Stockholm 2010.

[3] Landman T, Splendore LDG. Pandemic Democracy: Elections and COVID-19. Journal of Risk Research 2020; pp. 1-7. https://doi.org/10.1080/13669877.2020.1765003

[4] Akuamoah E. The Year 2020, COVID-19 and Elections in Africa. COVID-19 and Elections in Africa, May 5, 2020. https://doi.org/10.2139/ssrn.3596662

[5] Soanes C, Stevenson A. (Eds.). Concise Oxford English Dictionary. Oxford: Oxford University Press 2004; Vol. 11.

[6] Stevenson A, (Ed.). Oxford Dictionary of English. USA: Oxford University Press 2010.

[7] Adisa O. Electoral Fraud and the Transition Process in Nigeria's Fourth Republic (Case study of Ekiti State). Unpublished $\mathrm{PhD}$ Thesis submitted to the College of Humanities, University of KwaZulu-Natal, South Africa 2019.

[8] Oche O. Governance in Africa and the NEPAD Initiative. NEPAD for Journalists 2004; 61.

[9] UNDP, U. Human Development Report 2009 Overcoming Barriers: Human Mobility and Development. United Nations Development Programme 2009.

[10] Dyer O. COVID-19: Black people and other minorities are hardest hit in US. BMJ 2020; p. 369. https://doi.org/10.1136/bmj.m1483

[11] Asuelime TL. An Overview of the State of Electoral Justice in Zimbabwe. African Renaissance 2019; 16(1): 199-216. https://doi.org/10.31920/2516-5305/2019/S1n1a10

[12] Electoral Integrity Group. Towards an International Statement of the Principles of Electoral Justice. The Accra Guiding Principles. September 15 2011. Available at https://integrityaction.org/sites/default/files/training materials/ ELECTORAL\%20JUSTICE\%20PRINCIPLES\%20\%28THE\% 20ACCRA\%20PRINCIPLES\%29\%2CRevised\%20MAY2016 $\% 20 \% 2 C E n g l i s h \_0 . p d f$. [Accessed 26 August 2019].

[13] Schedler A. The nested game of democratisation by elections. International Political Science Review 2002; 23(1): 103-122. https://doi.org/10.1177/0192512102023001006 
[14] Adejumobi S. Elections in Africa: A fading shadow of democracy? International Political Science Review 2000; 21(1): 59-73. https://doi.org/10.1177/0192512100211004

[15] Mozaffar S, Schedler A. The comparative study of electoral governance-introduction. International Political Science Review 2002; 23(1): 5-27. https://doi.org/10.1177/0192512102023001001

[16] Ebirim SI. Assessment of the Performance of Independent National Electoral Commission (INEC) in the 2011 Gubernatorial Elections in South Eastern Nigeria. Global Journal of Political science and Administration: European Centre for Research, Training and Development ECRTD, 2013; 1(2).

[17] Bamisaye OA, Awofeso O. (Eds.). Democracy and Democratic Practice in Nigeria: Issues, Challenges and Prospects. Lagos: MacGrace Publishers 2011.

[18] Oche SA. Electoral Violence and National Security in Nigeria. Africa Journal of International Affairs 1997; 28(1\&2).

[19] Schumpeter J. Capitalism, Socialism and Democracy. London and New York: George Allen and Unwin 1994.

[20] Nnadozie U. History of elections in Nigeria. In: Jega A, and Oke I, (Eds.) Elections and the future of democracy in Nigeria. Nigeria: Nigerian Political Association 2007.

[21] Przeworski A, Limongi F. Selection, counterfactuals and comparisons. New York: New York University 1996.

[22] Huntington P. "The third wave": Democratisation in the late Twentieth Century. Oklahoma: University of Oklahoma Press 1991.

[23] Ozor FU. Challenges of Education for Democracy in the Gambia. African Journal of Teacher Education 2010; 1(1). https://doi.org/10.21083/ajote.v1i1.1588

[24] Hounkpe M, Gueye A. The Role of Security Forces in the Electoral Process: The Case of Six West African Countries. Abuja: Friedrich-Ebert-Stitfung 2010. Available at: https://www.ifes.org/news/voting-during-covid-19-whatscares-people-most [Accessed 26 August 2019].

[25] Eya N. Electoral process, electoral malpractices, and electoral violence. Enugu: Sages Publications Nigeria Ltd. 2003.
[26] Norris P, Wynter T, Grömping M, Cameron SM. The year in elections, 2017 mid-year update. The Electoral Integrity Project 2017. https://doi.org/10.1093/oso/9780190934163.001.0001

[27] Ayeni T. Nigerian Political elite fight it out for Edo State. The African Report 2020. Available at: https://www.theafricareport.com/36343/nigerias-political-elitefight-it-out-for-edo-state/. [Accessed August 7, 2020].

[28] Akinpelu Y. Timeline: Obaseki vs Oshiomhole: From political sweethearts to implacable foes. Premium Times 2020. Available at: https://www.premiumtimesng.com/news/topnews/399505-timeline-obaseki-vs-oshiomhole-from-politicalsweethearts-to-implacable-foes.html [Accessed on August 19 2020].

[29] Uwugiaren I, Akinwale A, Emenyonu A. APC rules out indirect primaries in Edo State 2020. This Day. Available at: https://www.thisdaylive.com/index.php/2020/06/08/apc-rulesout-indirect-primary-in-edo-state/. [Accessed August 15 2020].

[30] The Punch. Edo Primaries: APC dares Obaseki, refuses to apply for permit 2020. Available at: https://punchng.com/edoprimaries-apc-dares-obaseki-refuses-to-apply-for-permit/. [Accessed August 21 2020]

[31] Okocha C, Emenyonu A. APC, PDP intensify battle for Edo trade words over violence 2020. This Day. Available at: https://www.thisdaylive.com/index.php/2020/07/27/apc-pdpintensify-battle-for-edo-trade-words-over-violence/. [Accessed 20 August 2020].

[32] Adenekan S. Edo 2020: Group berates APC, PDP over tension ahead of polls. Premium Times 2020. Available at: https://www.premiumtimesng.com/news/more-news/408515edo-2020-group-berates-apc-pdp-over-tension-ahead-ofpoll.html. [Accessed on 15 August 2020].

[33] Sithole T, Asuelime LE. The Role of the African Union in Post-Election Violence in Kenya. African Journal of Governance and Development 2017; 6(2): 98-122.

[34] Asuelime LE. A Coup or not a Coup: That is the Question in Zimbabwe. Journal of African Foreign Affairs 2018; 5(1): 524.

https://doi.org/10.31920/2056-5658/2018/v5n1a1

\section{https://doi.org/10.6000/2292-2598.2021.09.02.7}

(C) 2021 Adisa and Asuelime; Licensee Lifescience Global.

This is an open access article licensed under the terms of the Creative Commons Attribution Non-Commercial License (http://creativecommons.org/licenses/by-nc/3.0/) which permits unrestricted, non-commercial use, distribution and reproduction in any medium, provided the work is properly cited. 